\title{
GIS APPROACH GEOSPATIAL APPLICATION FOR SEISMIC
}

\section{MICROZONATION STUDY}

\author{
C 2018 G.P. Ganapathy ${ }^{1}$, Associate Professor, Phd., \\ V.B. Zaalishvili2, Sc. Doctor (Phyth.-Math.), Prof., \\ D.A. Mel'kov², Sc. Candidate (Tech.), V.B. Svalova ${ }^{3}$, Sc. Candidate (Phyth.-Math.), \\ A.V. Nikolaev ${ }^{3}$, Sc. Doctor (Phyth.-Math.), Prof. \\ ${ }^{1}$ Centre for Disaster Mitigation and Management, Vellore Institute of Technology (VIT), \\ Vellore, 632014, India, e-mail: seismogans@yahoo.com; \\ ${ }^{2}$ Geophysical institute VSC RAS, Russia, 362002, RNO-Alania, Vladikavkaz, \\ Markov Str., 93 a, e-mail: cgi_ras@mail.ru;
}

${ }^{3}$ Sergeev Institute of Environmental Geoscience of the RAS, Russia, 101000, Moscow, Ulansky pereulok, 13, building, 2, e-mail: inter@geoenv.ru

In the paper GIS approach for seismic microzonation map compilation is presented. Approaches of Indian and Russian seismic microzonation practice are considered and compilated in express GIS technique. A first level seismic microzonation map of Chennai city has been produced with a GIS platform using the themes, viz, Peak Ground Acceleration (PGA), Shear wave velocity at $3 \mathrm{~m}$, Geology, Ground water fluctuation and bed rock depth. The peak ground acceleration for these seismic sources were estimated based on the attenuation relationship and the maximum PGA for Chennai is $0.176 \mathrm{~g}$ and for Vladikavkaz $0.2 \mathrm{~g}$ (for $5 \%$ exceedance probability). The seismic microzonation analysis involved grid datasets (the discrete datasets from different themes were converted to grids) to compute the final seismic hazard grid through integration and weightage analysis of the source themes. The Chennai city has been classified into three broad zones, viz, High, Moderate and Low Seismic Hazard. Vladikavkaz city microzonation map was presented in MSK-64 scale. In both approaches shear wave velocities was one of the basic instrumental data. Using as initial data of the scenario synthesized records, taking into account the characteristics of faults, takes into account the transformation of the original accelerograms stipulated by soil properties of the territory.

Keywords: seismic hazard, microzonation, geoformation system, site rating, accelerograms.

\subsection{Introduction}

Earthquake hazard zonation for urban areas, mostly referred as seismic microzonation, is the first and most important step towards a seismic risk analysis and mitigation strategy in densely populated regions [Siefko Slob et al, 2002]. As it has been observed from many earthquake scenarios the major damage to buildings and man-made structures is mostly found in the area of soft sediments [Imtiyaz A. Parvez, 2003]. As a result, even relatively minor events can be the source of huge socio-economic disasters. The earthquake of $12^{\text {th }}$ October 1992 with M 5,4 in Egypt, where the buildings were not earthquake resistant, resulted in 554 deaths, 20,000 people injured with a reported loss of one million US\$ [El-Sayed et al., 2001]. It is to be recalled that the present study area (Figure 1) Chennai City has experienced three earthquakes of $M \geq 5,0$ in 1807,1816 and 1823. Also the population of the city was 43,43lakh in 2001 and projected to 53,43 lakh in 2011 Census of India [Census, 2001].

A number of water bodies (lakes and ponds), which existed in Chennai in the early 
period of this century, have been filled up with garbage and transport sand and clay [CGWB Report, 1993]. The sand dunes and beach ridges in the coastal belt of Chennai have also been converted into residential areas and as a result, the true landform has been altered. The marshy land existing north of Adayar river has been transformed into a residential area. Buildings constructed in these areas would be highly vulnerable to earthquakes. The city has shallow water table and its major part is covered by thick alluvium of a maximum depth of $28 \mathrm{~m}$. Such being the case, Chennai is liable for sitespecific amplification of seismic motion. Safety of this city is extremely important for safeguarding human lives and property. This paper aims at produce first level seismic microzonation map of Chennai City.

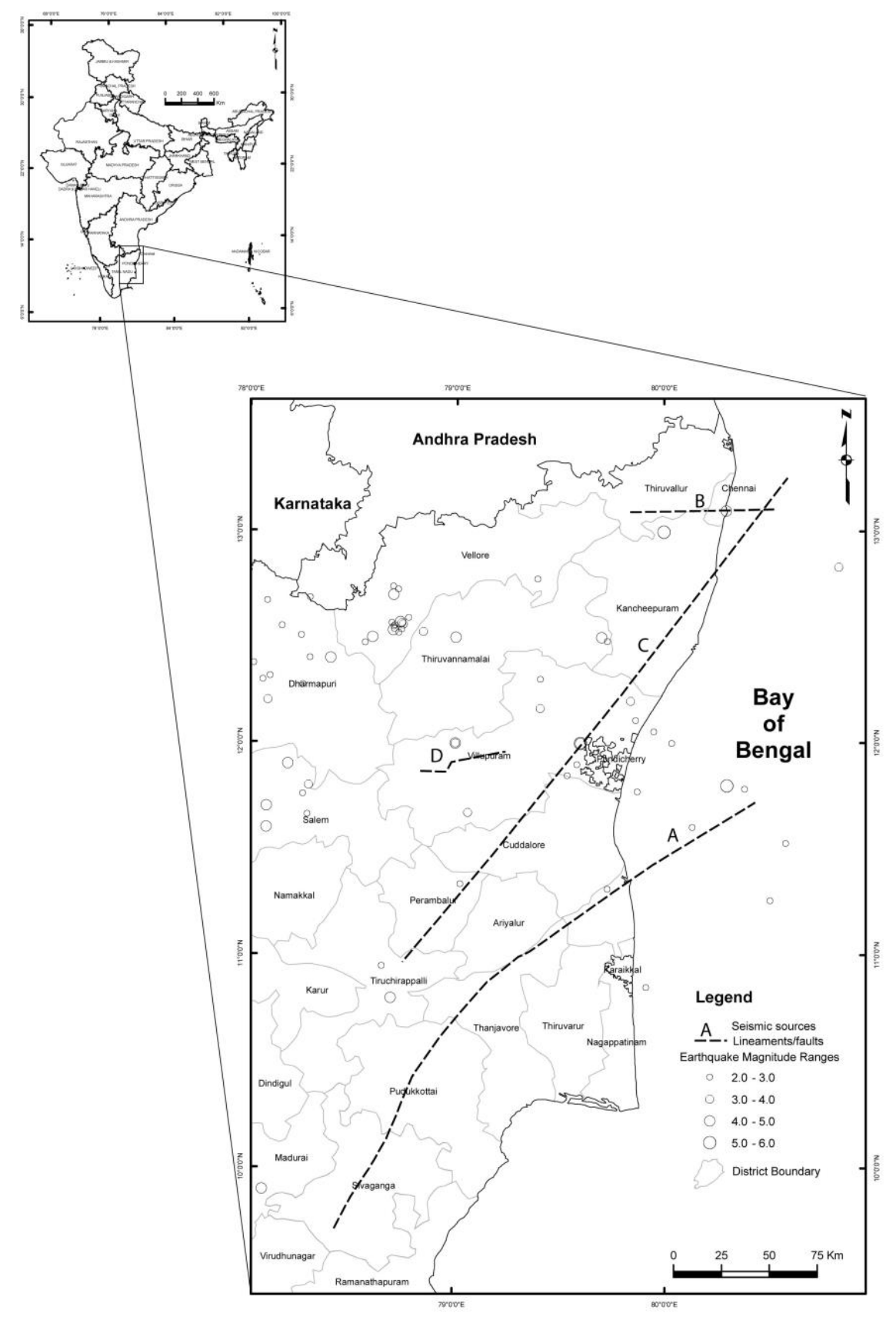

Fig. 1. Seismicity and seismic sources for Chennai City 


\subsection{Data used}

The geological, ground motion, seismotectonic features and ground water conditions are the input to assess the seismic hazard for Chennai. The involved base line data are discussed in the following headings.

\subsection{Peak Ground Acceleration}

A seismicity study is of great importance to understand the dynamic behaviour of the earth and is useful to determine the earthquake hazard in a specific region. In order to understand the seismicity of Chennai and its vicinity, data regarding spatial locations of earthquakes and their magnitudes have been collected for a period of around 200 years (1807-2006) from various sources and have been used for the present study. For the historical earthquakes general locations are used for which "generalized" epicentral coordinates are available. The total number of earthquakes identified from these sources for the present study is 103. Out of the total 103 earthquakes/earth tremors 48, 23, 21, 10 and 1 incidences have been in the magnitude range of 2,0-2,9, 3,0-3,9, 4,0-4,9, 5,0-5, and $\geq 6,0$ respectively. 52 earthquakes ( $51 \%$ of overall) are of $M \geq 3$ in the past 200 years of seismic history [Ganapathy, 2005].

Analysis of tectonic lineaments and faults helps in understanding the regional seismotectonic activity of the area. For the present study seismotectonic details are collected from the report published by Central Ground Water Board, Chennai. The NESW trending Archaean boundary fault is located in Chennai and separates two basins. The southern one is shallow without Gondwana sediments. The northern basin has extensive Gondwana sediments beneath the alluvium. The presence of bedding joints, shears and micro folding in core samples are indicative of the extensive tectonic disturbance in the post-Gondwana period. The Adayar fault is shown in Figure 1 and this weak zone is followed by the flow of Adayar river.

Based on the seismicity and seismogenic systems 4 zones have been delineated as potential sources for Chennai city and its vicinity of $200 \mathrm{~km}$ radius. These seismic potential sources are named based on its spatial locations. These sources generated earthquakes in the range of 3.2 to 5,3 in the past earthquake history of 200 years. In the present study the largest earthquake occurred in the instrumental time-period with good accuracy of the recorded event is taken into consideration. Estimation of ground motion in terms of Peak Ground Acceleration (PGA) at bedrock level can be determined using attenuation relationships. A variation of this approach uses the reference and site recordings as for their different site-source distances. This was done using ratios of hypocentral distance by Borcherdt and Glassmoyer (1994). Distance corrections incorporating frequencydependent attenuation have been implemented by Borcherdt [2001].

For the regions where strong motion data are not available for such analysis, the attenuation relationships developed for other regions can be used based on the resemblance of the seismotectonic characteristics of both the regions. Abrahamson and Litehiser [1989] have proposed an attenuation model for PGA based on 585 strong ground motion records from 76 worldwide earthquakes. A suitable attenuation relationship developed by Iyengar and Raghukanth [2004] for Peninsular India applicable to Chennai is used for the present study.

The determined PGA for the four identified potential seismic sources for the city of Chennai is in the range of $0.176 \mathrm{~g}$ to 0.078 (Table 1). The maximum PGA of 0.176 would be caused by the East west trending in the southern part of Chennai (Figure 2). This fault has been associated with 4 earthquake incidences in the past 200 year earthquake history and the Maximum magnitude (Mmax) so far generated is 5,3. 
Table 1.

Estimated Peak Ground Acceleration (PGA) values Chennai city by the closes potential seismic sources

\begin{tabular}{ccccc}
\hline $\begin{array}{c}\text { Seismic } \\
\text { Sources }\end{array}$ & $\begin{array}{c}\text { Cumulative } \\
\text { Earthquakes }\end{array}$ & $\begin{array}{c}\text { Maximum } \\
\text { Magnitude }\end{array}$ & $\begin{array}{c}\text { Epicentral } \\
\text { Distance from } \\
\text { Chennai }\end{array}$ & $\begin{array}{c}\text { Estimated Peak } \\
\text { Ground } \\
\text { Acceleration }\end{array}$ \\
\hline A & 5 & 5.6 & 156 & 0.176 \\
B & 1 & 5.3 & 10 & 0.107 \\
C & 3 & 5.0 & 155 & 0.078 \\
D & 3 & 5.0 & 174 & 0.078
\end{tabular}

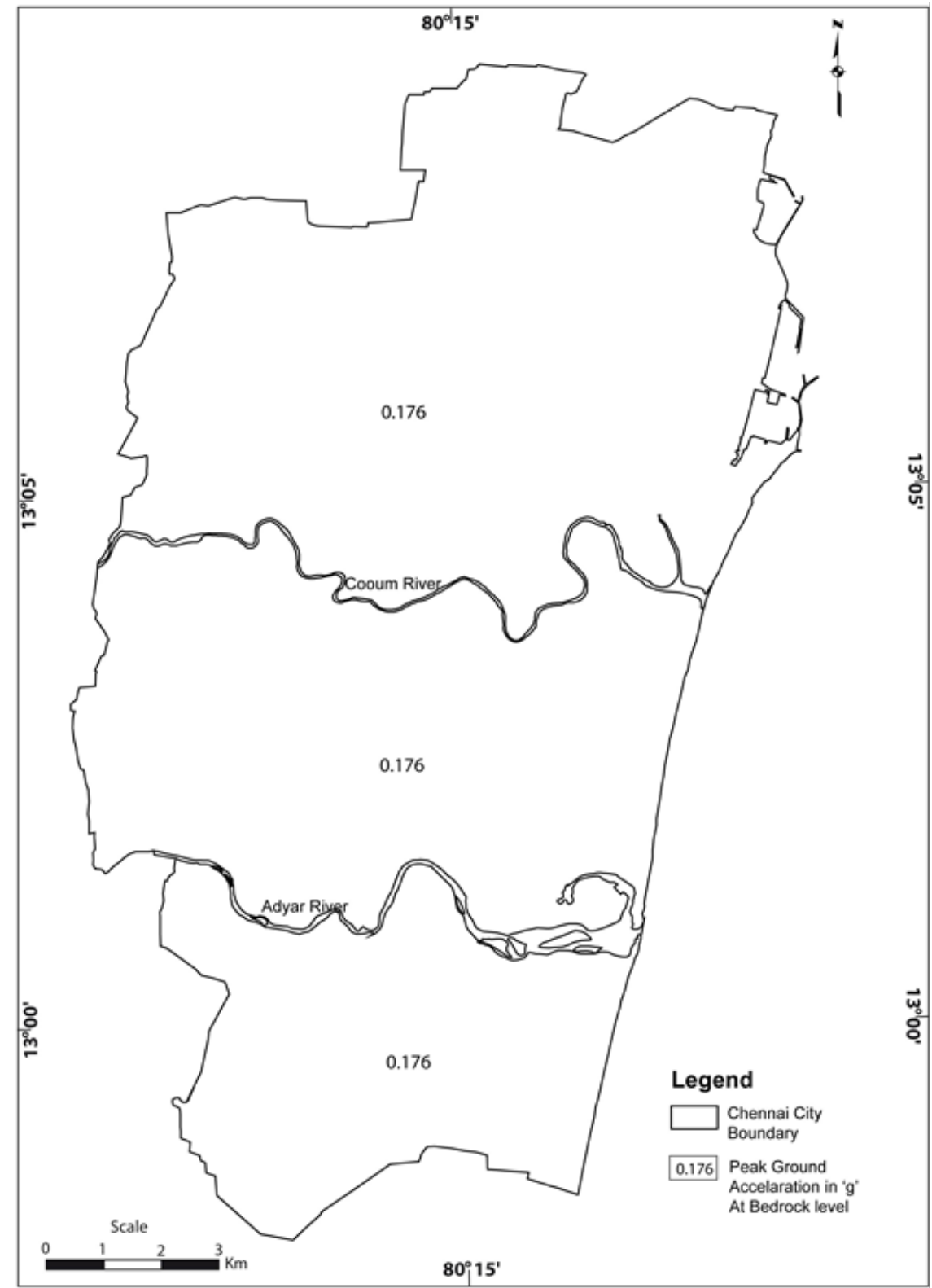

Fig. 2. Estimated Peak Ground Acceleration for Chennai City 


\subsection{Shear wave velocity from Geotechnical Data}

Chennai City has many multi-storey buildings and these buildings have been constructed based on geotechnical studies through Standard Penetration Tests (SPT). 503 borehole data have been obtained from various geotechnical agencies including SPT - N values, and various characteristics of soils in depths. The borehole locations are given in Figure 3. The depth of the boreholes is in the range of 2,0 to $32 \mathrm{~m}$. Only 43 boreholes are penetrated to down to basement. The "N" values observed in the field, using the standard penetration test equipment, and the standard test procedure were corrected for (a) overburden stress (b) hammer energy (c) borehole diameter (d) rod length, and (e) presence or absence of liner.

Based upon the distribution of ' $N$ ' values in different depths, average SPT $-\mathrm{N}$ value contour maps were prepared for $3 \mathrm{~m}$ depth. The relative density of sand and clay is categorized based on the SPT - N values (Karl Terzaghi and Peck, 1967) details are related with shear wave velocity and it is given in Table 2 .

Table 2.

'N' value Vs Shear wave velocity

\begin{tabular}{ccc}
\hline $\begin{array}{c}\text { 'N' value } \\
\text { Relative Density of Sand }\end{array}$ & $\begin{array}{c}\text { 'N' value } \\
\text { Relative Density of Clay }\end{array}$ & Shear wave Velocity \\
\hline$<4$ & $<2$ & $<50$ \\
$4-10$ & $2-8$ & $50-130$ \\
$10-30$ & $8-15$ & $130-165$ \\
$30-50$ & $15-30$ & $165-185$ \\
$>50$ & $>30$ & $185-350$ \\
\hline
\end{tabular}

The shear wave velocity is an important parameter to assess the strength of the soil. Soil profiles are characterized by shear wave velocity because it is a key indicator of soil susceptibility. Shear wave velocity can be estimated from correlations with the Standard Penetration Test (SPT), water content and soil type. Researchers developing empirical attenuation relations have attempted to use site classification based on average shear wave velocity to account for differences in site response [Boore and Joyner, 1982]. The result of average shear wave velocity have been obtained for Chennai for the depth of $0-3 \mathrm{~m}$ by using the empirical relationship proposed by Imai and Yoshimura [1970], Ohba and Goto [1970]. The contours of average shear wave velocity at $3 \mathrm{~m}$ depth is prepared by using Arc-GIS -Spatial Analyst software by Interpolating Raster by Inverse distance weighted method and presented in Figure 4. 


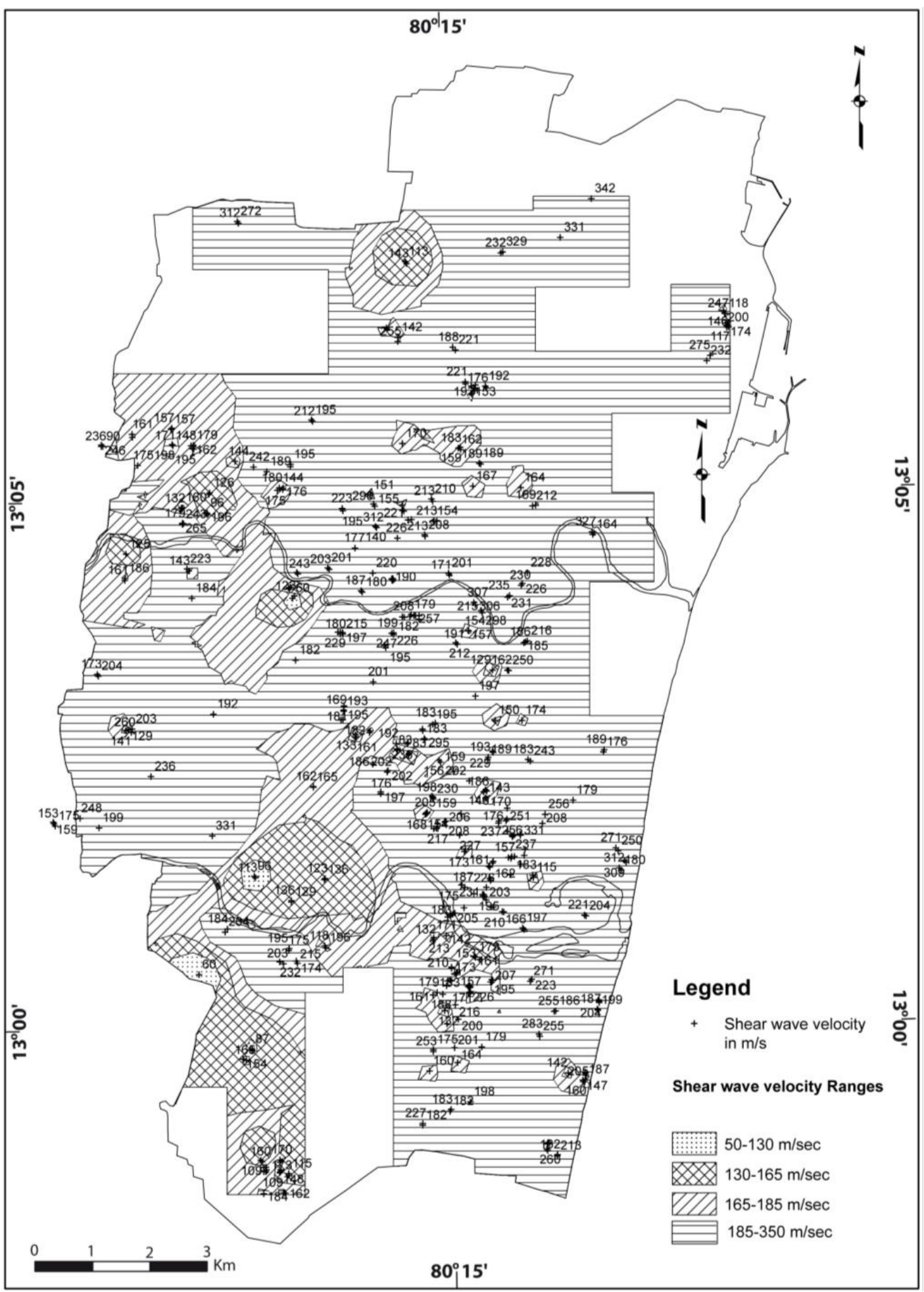

Fig. 4. Estimated shear wave velocity at $3 m$ depth. 


\subsection{Geology}

The Archaean crystalline rocks, Gondwana \& Tertiary sediments and Recent alluvium are the three group of geological formations found in Chennai (Figure 5). Most of the geological formations are concealed since they are overlain by the alluvial materials except for a few exposures of crystalline rocks of charnockites in the southwestern part of Chennai [CGWB Report, 1993].

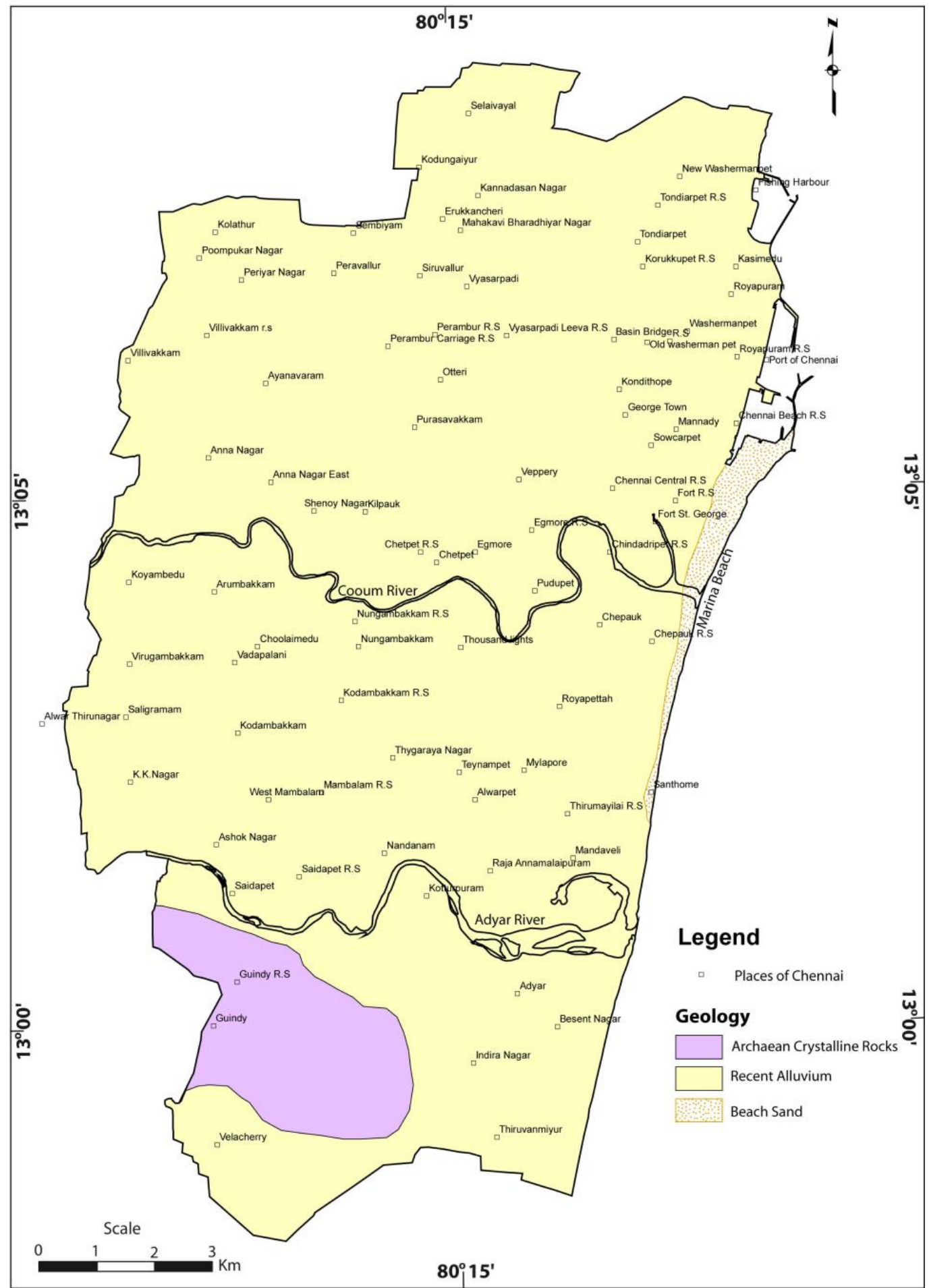

Fig. 5. Geology of Chennai City 
The Archaean crystalline rocks of the city comprise chiefly of charnockites, gneisses, and the associated basic and ultrabasic intrusives. The charnockites represent the major rock type in the area of Saidapet. The crystalline rocks are weathered and jointed/fractured. The degree and depth of weathering varies from place to place and the thickness of the weathered mantle varies from less than $1 \mathrm{~m}$ to about $12 \mathrm{~m}$ in the city.

The Gondwana shale is exposed in Adayar river near Ramavaram (southern part of Chennai). The Gondwana - Archaean contact is a fault concealed by alluvium. The Gondwana shale is black to dark grey in colour and highly jointed / fractured. The shale is encountered in a number of boreholes and its thickness varies from $24 \mathrm{~m}$ in Kilpauk, area through $20 \mathrm{~m}$ in Ashok Nagar area to more than $139 \mathrm{~m}$ in Koyambedu area.

The Tertiary sandstones are reddish brown to grayish white and white in colours friable and mottled. The occurrence of the Tertiary in Chennai is not well demarcated. However, the sandstones encountered in some of the boreholes below alluvium in Perambur, Alwarpet, Anna Nagar and Royapuram areas are different from the compact dark coloured shale of Gondwana Group and they may belong to the Tertiary. Probably Tertiary rocks are deposited on the eroded Gondwana System and are overlain by river alluvium.

The alluvium covers the major part of Chennai. It consists of sand, silts and clays. The thickness of alluvium varies from place to place and a maximum of $28 \mathrm{~m}$ is encountered in drilled boreholes of north Chennai near Perambur.

\subsection{Depth to Bedrock}

Borehole data are the only reliable data to estimate the depth to bedrock, which is an important key parameter in assessing the soil column thickness over it. The bedrock configuration of a site will give an idea about the basement topography. The basement topography will help in the study of frequencies and amplitudes of ground motions. This will help to identify high (as well as low) seismic risk areas from the point of view of wave propagation influence.

The basement is somewhat shallow in the southern side of crystalline basement near Saidapet and Guindy Park $(0-5 \mathrm{~m})$. The basement is relatively high in the northern part of the city $(20-40 \mathrm{~m})$. The western Central part of the city had a very high basement depth of $40-80 \mathrm{~m}$. The generalised basement contour map needs to be refined with the forthcoming of more and more data. The sub-surface geology and basement configuration is presented in Figure 6. 


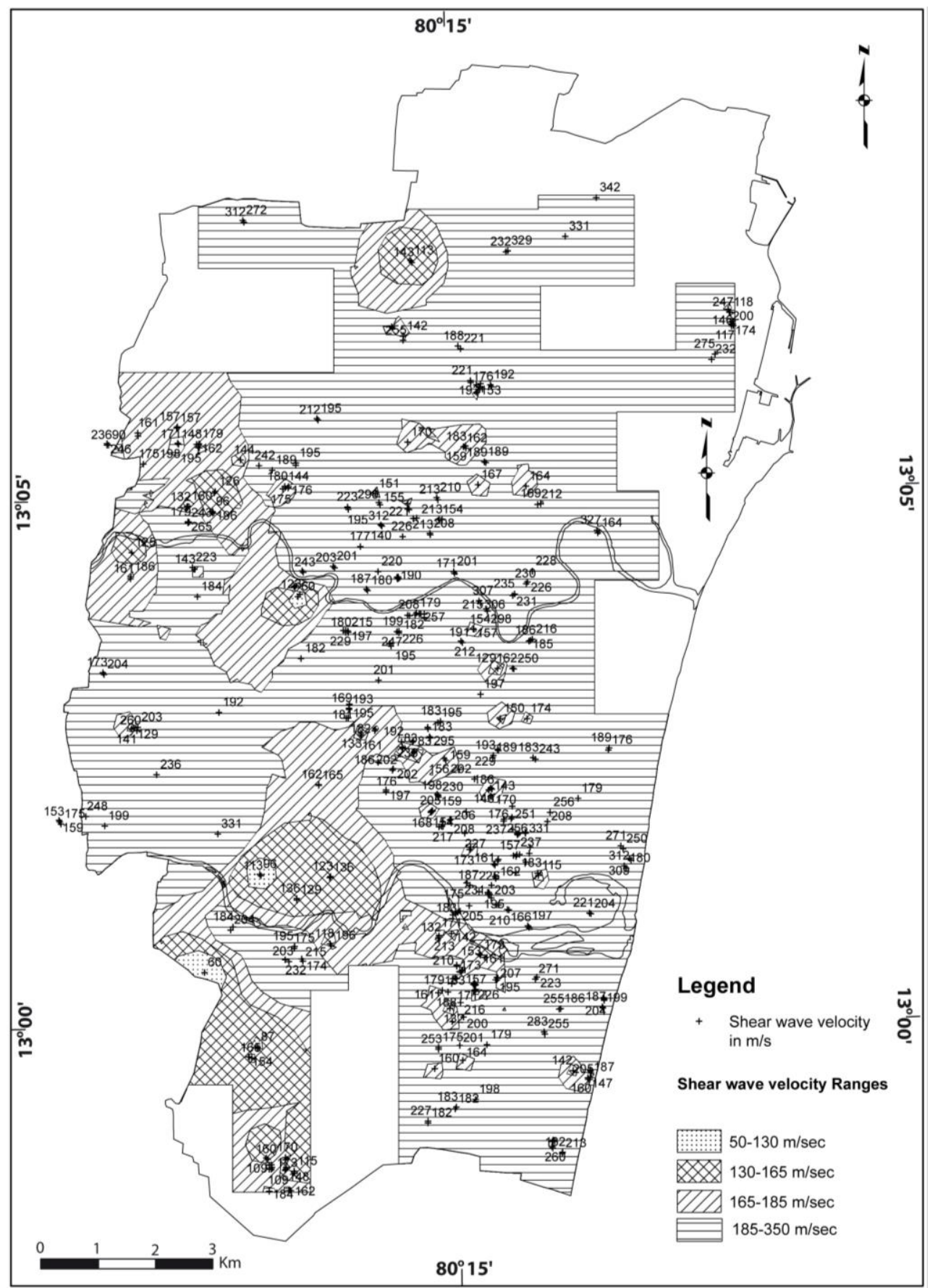

Fig. 6. Map showing the depth to basement of rock at Chennai City

\subsection{Depth to Water Table and Water Level Fluctuation}

The depth of water level and water level fluctuation contours are presented in Figure 7. This ranges between 1,15 and $0,93 \mathrm{mbgl}$ where as it is shallow in the range of 0,15 and $5,63 \mathrm{~m} \mathrm{bgl}$ in post-monsoon period. It can be seen that the water table generally follows the topography with gentle slopes towards the rivers as well as the sea. The water table elevation varies from 3,5 m above MSL to 2,2 m below MSL. The fluctuation is high in selected stations like Besant Nagar, and Aminjikarai, an indication of higher draft in selected pockets. 


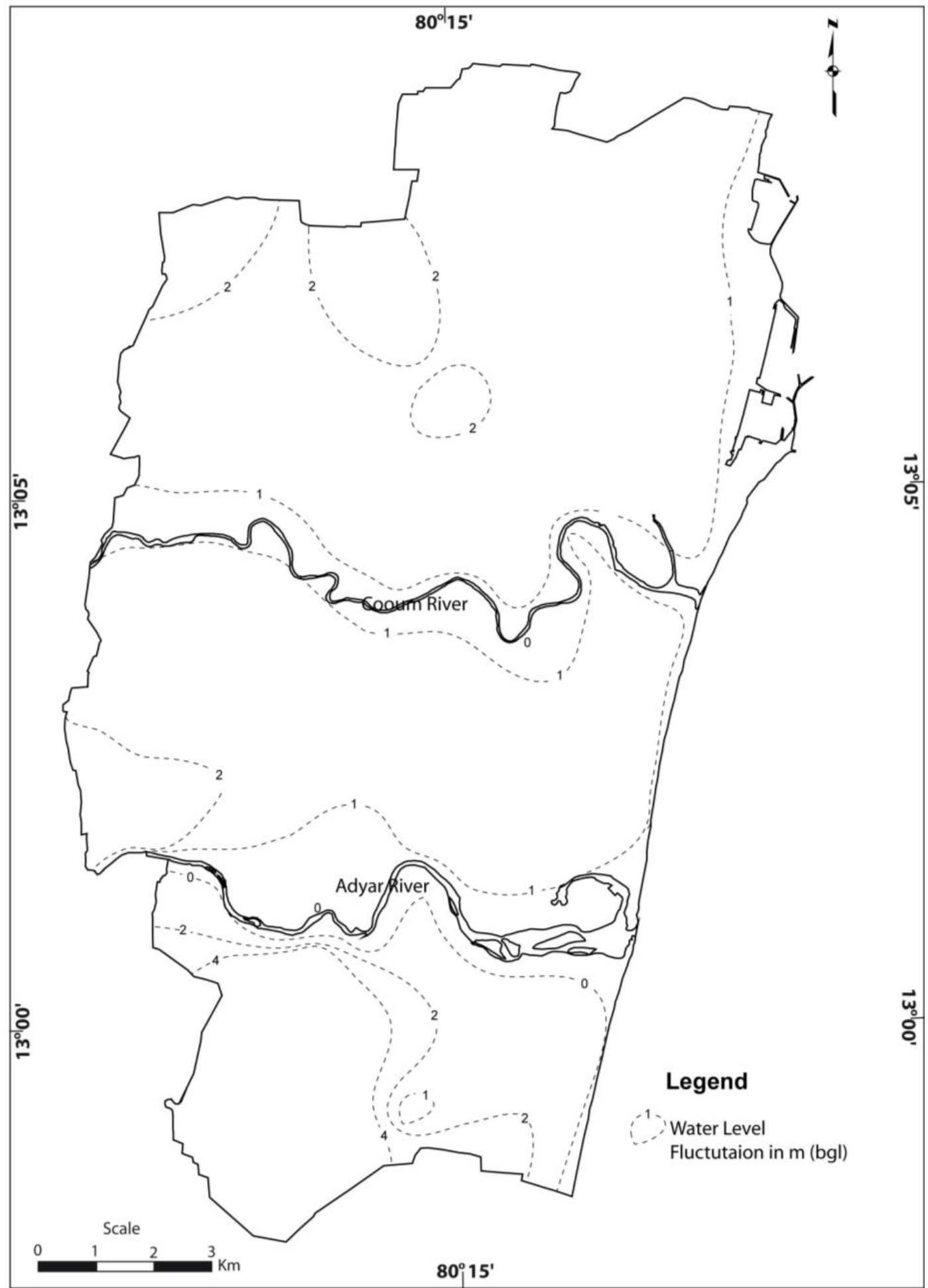

Fig. 7. Map showing the water level fluctuation at Chennai City

\subsection{Approach}

There are a variety of subjective decision rules and most commonly used one being the analytic hierarchy process (AHP) of Saaty [1980] and weighted linear combination (WLC) [Barredo et al., 2000; Ayalew and Yamagishi, 2004; Ayalew et al., 2004]. The 
analysis has been carried out following Saaty's Analytical Hierarchy Process (AHP). Analytic Hierarchy Process (AHP) is one of Multi Criteria decision making method that was originally developed by Prof. Thomas L. Saaty. In short, it is a method to derive ratio scales from paired comparisons. It uses hierarchical structures to quantify relative priorities for a given set of elements on a ratio scale, which is based on the discernment of the user. From the judgments between two particular elements, a pair wise comparison matrix is constructed on a scale of 1-5, 1 indicating that the two elements are equally important, and 5 implying that one element is more important than the other. If an element is less significant than the other then it is indicated by reciprocals of $1-5$ values (i.e., $1 / 1$ to $1 / 5$ ). The pair wise comparison matrix prepared is used to derive the individual normalized weights of each element. The weights of each criterion are calculated by averaging the values of each row of the matrix. These weights also add up to 1 and can be used in deriving the weighted sums of rating for each region of polygons of the mapped layers. This approach has also been successfully used by William K. Mohanty et al, 2007 for the similar type of microzonation studies.

The features of each thematic map are also normalized between 0 and 1 [Nath, 2004] to ensure that no layer exerts an influence beyond its determined weight. The weightage factor of each layer calculated based on expert choice. For the study the paired comparison matrix is prepared for the five themes (PGA contour, soil, geology, groundwater fluctuation and bedrock depth) as shown in Table 3. Following the AHP, the thematic maps are assigned weights on a scale of 1-5 depending on their contribution to seismic hazard. The higher weight is assigned to the theme that contributes more to the hazard and in this case the highest weight is given to the PGA contour theme. The weights obtained for each theme are: PGA $(0,333)$, Shear wave Velocity $(0,266)$, geology $(0,20)$, groundwater $(0,133)$ and bedrock depth $(0,066)$. The normalized ratings for thematic layers are given in Table 4. The feature of each themes normalised between 0 and 1.

Table 3.

Assigned weights for the thematic maps for GIS Integration

\begin{tabular}{ccccccc}
\hline Themes & PGA & Soil & Geology & $\begin{array}{c}\text { Ground } \\
\text { Water }\end{array}$ & Bed rock & Weightage \\
\hline PGA & 1 & $5 / 4$ & $5 / 3$ & $5 / 2$ & $5 / 1$ & 0.3333 \\
$\begin{array}{c}\text { Shear Wave } \\
\text { Velocity }\end{array}$ & $4 / 5$ & 1 & $4 / 3$ & $4 / 2$ & $4 / 1$ & 0.2666 \\
$\begin{array}{c}\text { Geology } \\
\text { Ground }\end{array}$ & $3 / 5$ & $3 / 4$ & 1 & $3 / 2$ & $3 / 1$ & 0.2000 \\
Water & $2 / 5$ & $2 / 4$ & $2 / 3$ & 1 & $2 / 1$ & 0.1333 \\
Bedrock & $1 / 5$ & $1 / 4$ & $1 / 3$ & $1 / 2$ & 1 & 0.0666 \\
\hline
\end{tabular}


Table 4.

Normalised ratings of the thematic layers

\begin{tabular}{cccccc}
\hline \multirow{2}{*}{ Themes } & Weightage & \multicolumn{5}{c}{ Normalised Values } \\
\cline { 3 - 6 } & & 4 & 3 & 2 & 1 \\
\hline PGA (in g) & 0.3333 & - & 0.176 & - & - \\
$\begin{array}{c}\text { Shear Wave Velocity } \\
(\mathrm{m} / \mathrm{sec})\end{array}$ & 0.2666 & $50-130$ & $130-165$ & $165-185$ & $185-350$ \\
$\begin{array}{c}\text { Geology } \\
\text { Ground Water }\end{array}$ & 0.2000 & - & Alluvium & Beach Sand & Rock \\
$\begin{array}{c}\text { Fluctuation (m) } \\
\text { Bedrock (m) }\end{array}$ & 0.1333 & $0-2$ & $2-4$ & - & - \\
\hline
\end{tabular}

The obtained values are then incorporated in a GIS platform for the integration of all the thematic maps to obtain the seismic microzonation map of Chennai city. The integration of five thematic layers is integrated by the UNION and overlay operation in GIS.

\subsection{Seismic hazard map}

Chennai has various building types' wall materials and their percentage viz., the earthen walls $(9,59 \%)$ (mud, unbrick, brick), stone walls $(3,1 \%)$, burned brick walls (80,79\%), concrete walls (Nil), wood and Ekra walls (0,23\%), GI and other metal sheets $(0,21 \%)$, bamboo thatch, leaves, etc., $(6,1 \%)$ [Gupta, 2000]. It is seen that those worse affected in an earthquake (earthen and stone houses) account for 12,59\% and other brittle burned brick are $80,79 \%$ ie a total of $93,38 \%$ are vulnerable if shaken by an earthquake of moderate to severe intensity. Due to its rapid growth in civil construction, industry etc., a thorough knowledge of the seismicity is needed for adopting mitigation measures.

Chennai has been broadly classified into three zones, as high, moderate and low in terms of seismic hazard in an event of future earthquakes. Part of Chennai falls in seismically moderate to high hazard prone areas (Figure 8). The resultant map depicts that the high hazard areas are distributed in patches around Adayar River and few patches distributed below Cooum River in the south western part of the City. The areas in the southern part of Chennai represent lacustrine deposits in underlined by marine black clay as evident in Taramani areas. The maximum depth to basement is $14 \mathrm{~m}$. The central part of the city has mainly fluvial origin of flood plain deposits as evident from the flowing Adayar and Cooum rivers. The upstream portion of Adayar and Cooum rivers have moderate slope and in the down stream, the rivers are very gentle to flat in coastal areas. These areas in the northern part of City represent black clay and alluvium of marine origin with maximum depth to basement of $30 \mathrm{~m}$ and patches of these areas shows high hazard. The western and northwestern part of Chennai falls under moderate hazard. These areas represent the shale and clay of Gondwana age and are also it is correlated with lake fill deposits. The remaining areas are prone to low seismic hazard. It can be concluded that the half of the Chennai City is prone to moderate to high hazard. The resultant map provides regional pictures on seismic hazard of Chennai City and is useful information in construction planning of forthcoming buildings of the city. Also it is helpful as a base material to identify seismic risk of Chennai City. 


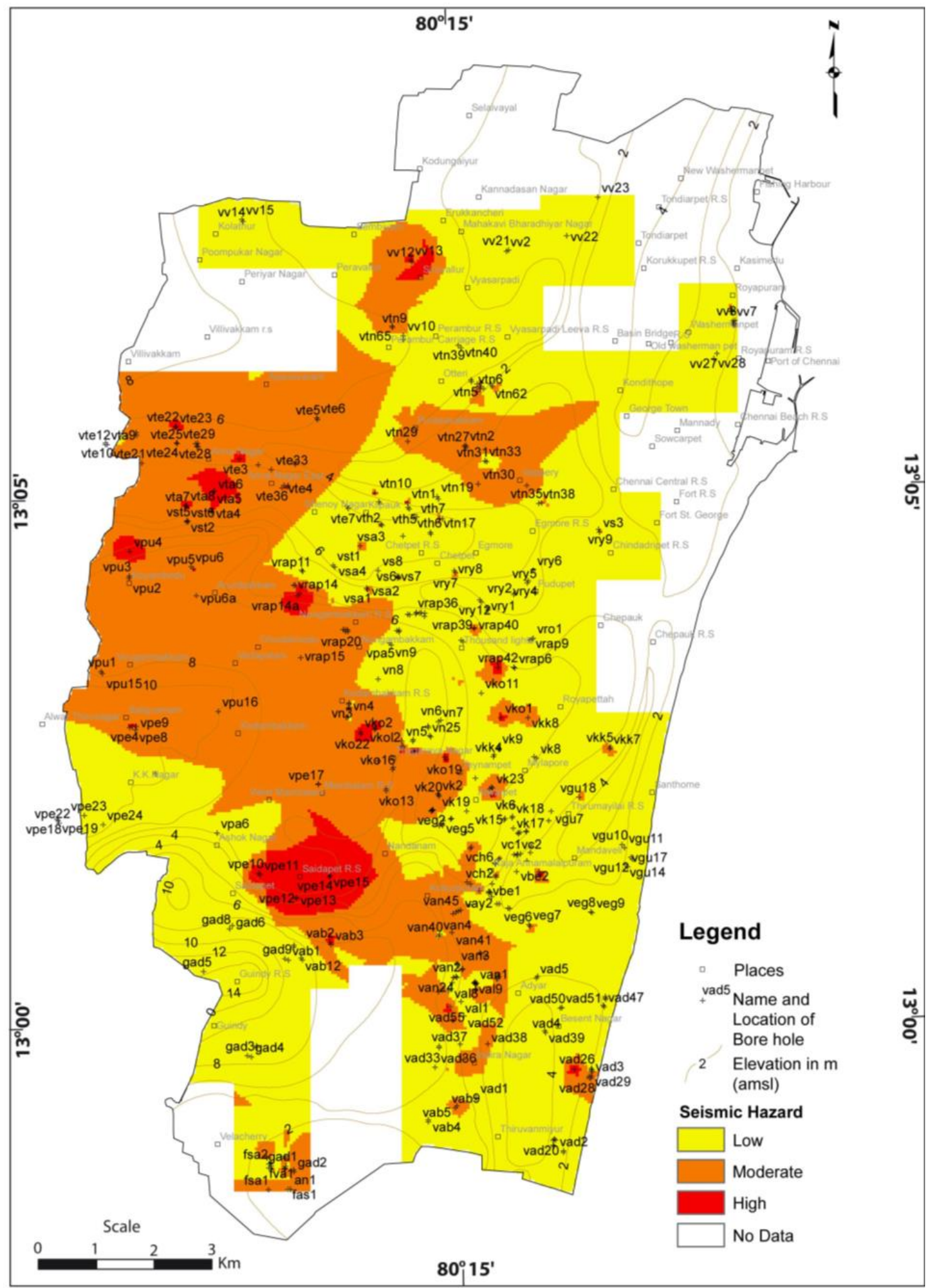

Fig. 8. First level seismic microzonation map of Chennai City 
Seismic microzonation (SMZ) can be viewed as a method of zoning of a city or a large construction site in sites with the same ground response for standard seismic effect of a certain level and assessment of the relative changes in the characteristics of vibrations on the surface relative to the characteristics of vibrations of so-called reference site to which the initial intensity is attributed. In Russia the reference sites are sites with average seismic properties of ground conditions of certain territory. In Armenia and Georgia sites with the worst ground conditions are generally considered as reference, although in some cases they can be averages [Zaalishvili, 2000]. In the United States the reference sites are Rock sites. In former USSR sites with standard ground conditions traditionally were chosen after macroseismic investigation of historical strong earthquakes.

Sites with the same intensity are combined in different seismic zones. Engineeringgeological, hydrogeological and geomorphological conditions are taken into account. On the other hand, the target of seismic microzonation is development of initial dataof various levels of seismic impacts for structural engineering and urban planning.

Modern principles of seismic microzonation used abroad require differentiation the territories indifferent types of ground conditions. The territory is divided into a grid with equal cells. Further the parameters of the forming characteristics of ground conditions in each of these cells are defined, which requires active use of GIS technology [Zaalishvili, Berezko, 1999]. In particular, such studies have been carried out in 2000, in the process of implementation of the international project for a large area of Tbilisi, with various types of soils, in different physical conditions [Zaalishvili et al., 2001].

In General, the process of seismic microzonation can be divided into three phases. In the first phase, initial regional seismic characteristics of the earthquake at rock level are determined for each cell. In the second stage, the site profiles are modeled on the basis of the results of the drilling and field testing. The third phase includes an analysis of the expected response of sites to evaluate characteristic of earthquake on the surface and interpreting the results of microzonation [Ansal et al., 2004, 2010]. When the available data of engineering geological zoning (usually the results of surveys of past years) do not correspond to modern requirements (for example, insufficient data on fill content in gravels), the instrumental studies based on some selected grounds in the territory is essential for the reliability of the final result.

In the paper approach used abroad is combined with techniques of RussianGeorgian school of seismic microzonation, especially of instrumental method which is the primary method of SMZ. Seismic process is a complex multifactor process, so final maps of seismic microzonation are based on the results of integrated use of instrumental, calculational and recently developed instrumental-calculation methods [Zaalishvili, 2006; Zaalishvili et al., 2007]. On the basis of this approach in $2010 \mathrm{SMZ}$ Map of Vladikavkaz city was developed (Figure 9). 


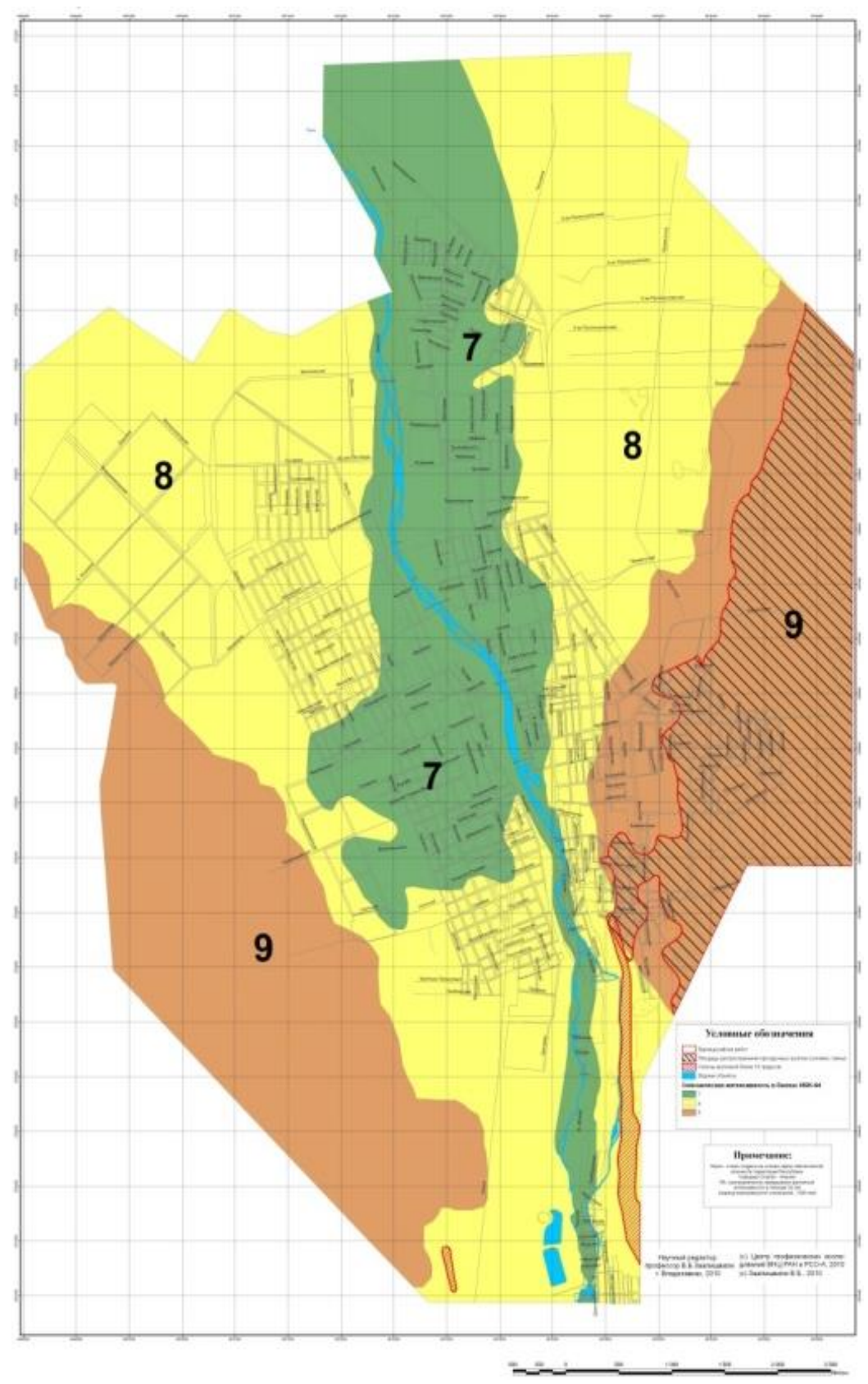

Fig. 9. Map of seismic microzonation of the territory of Vladikavkaz city

The possibility of creating the expected seismic impact with its specific features on the basis of taking into account the main characteristics of a particular fault or seismic source with a high seismic potential will be considered further. It should be noted that particular seismic sources move within a particular fault, and their "deviation" is largely determined by internal strains in the source and the geological depth structure of the territory.

\subsection{Specified seismic fault and design seismic motion}

Analysis and consequent account of initial accelerograms transformation will become the basis for site effect analysis at strong seismic loadings (Figure 10) [Zaalishvili et al., 2010]. 
Methods of such modeling are based on accordance of spectral properties of modeled and real earthquake. In a whole modeling accuracy depending on the purposes of total motion usage and what characteristics defining structural system behavior must be reproduced.
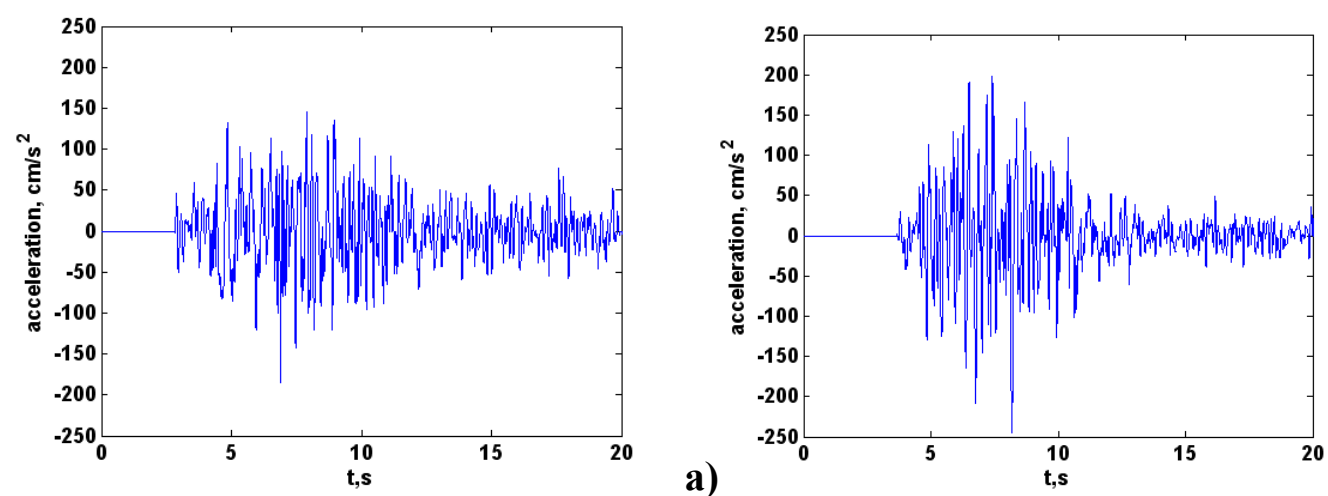

b)
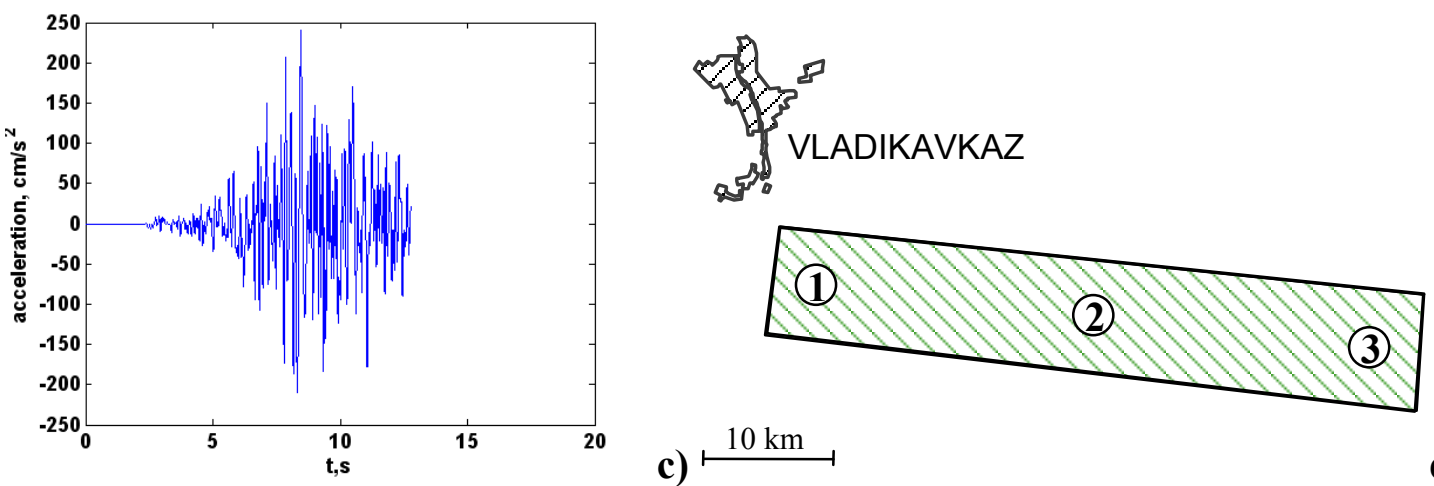

d)

Fig. 10. Synthetical accelerograms for different source locations: $a$-western part of fault; $b$ - middle part of fault; $c$ - eastern part of fault; $d$-scheme of sources of scenarios earthquakes

Earthquake source that is a region of rupture can be considered as point source only for much larger distances than fault size. At close distances effects of finite fault size become more significant. Those phenomena are mainly connected with finite rupture velocity, which causes energy radiation of different fault parts in different times and seismic waves are interference and causes directivity effects [Beresnev, Atkinson, 1997, 1998].

Let's compare amplitude spectra of obtained design accelerograms with spectrum of real earthquake from considering fault. Data analysis (Fig. 11 and Fig. 12) shows that spectra of calculated and real earthquakes in a whole are similar in their main parameters.

It must be noted that spectrum of vertical component of real earthquake is closer to design spectra. The last fact is quite obvious and is explained by proximity to earthquake source. Indeed, close earthquakes in general are characterized by predomination of vertical component. Record of TEA station (located in theater) was selected due to its location on dense gravel and has a minimal distortions caused by soil conditions.

Analysis of spectrum of weak earthquake shows that peaks are observed on 1,3 and $5,6 \mathrm{~Hz}$ (Fig. 12). In spectra of synthesize accelerograms mentioned amplitudes are also observed. At the same time medium response on strong earthquake, undoubtedly, differ from weak earthquake response. 


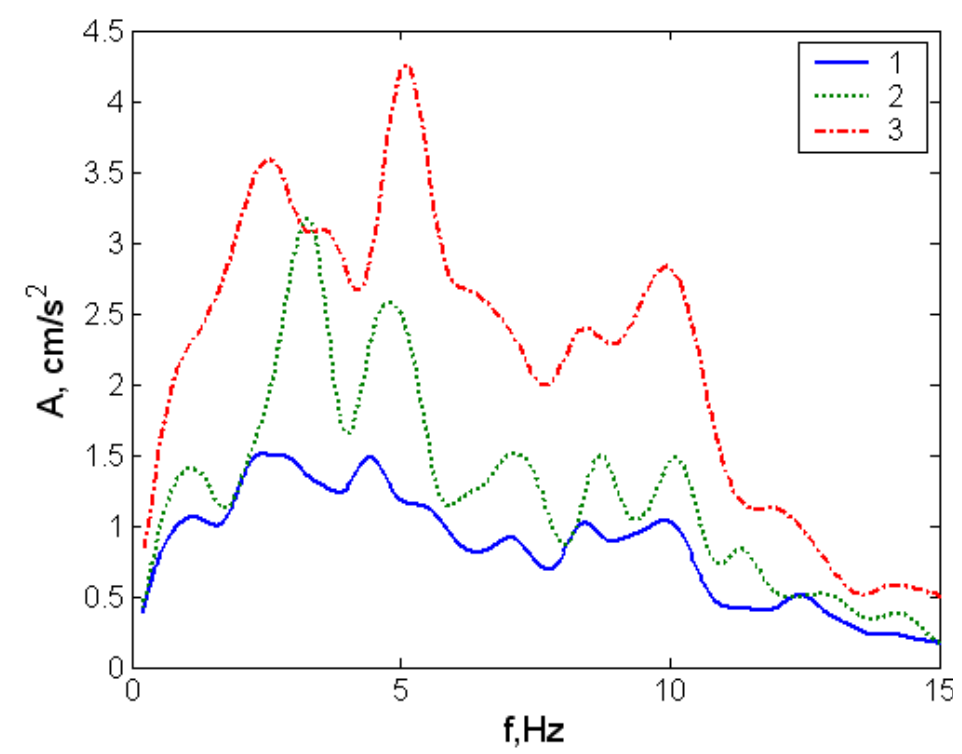

Fig. 11. Spectra of design accelerograms at different source locations of earthquake $M=7,1$ : 1 -western part of fault; 2 - middle part of fault; 3 - eastern part of fault

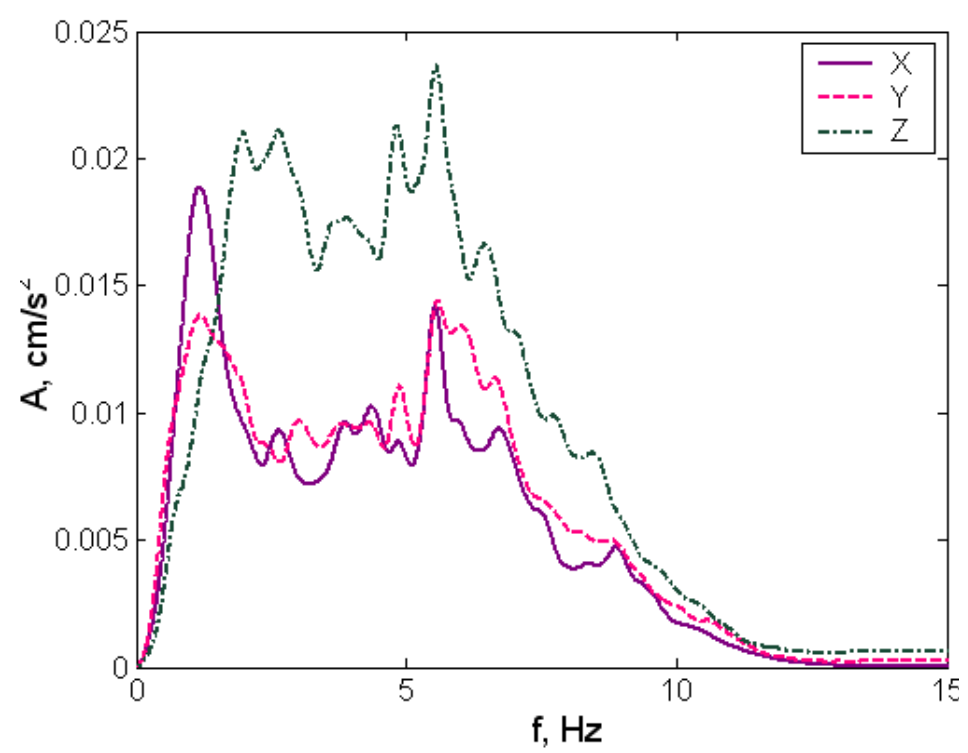

Fig. 12. Spectra of accelerograms of weak earthquake with epicenter in the zone of Vladikavkaz fault. (25.08.2005 10:25 GMT, $H=8 \mathrm{~km} M=2.5$ ).

Today traditional instrumental method of seismic microzonation does not allow obtaining intensity increments in accelerations due to traditional orientation on macroseismic intensity indexes. The exclusion is the case of investigation of strong earthquakes accelerations when instrumental records are obtained (in presence of accelerometer). At the same time investigations are conducted and the problem supposed to be solved.

On the other hand in recent years a new instrumental-calculation method was developed. New method is based on selection from database (including about 5000 earthquake records) soil conditions which are the most appropriate to real soil conditions of the investigated site. Then the selection of seismic records with certain parameters or their intervals follows (magnitude, epicentral distance, and source depth). Then maximal 
amplitudes are recalculated for given epicentral distances. Absorption coefficient can be calculated by attenuation model for given region.

\section{Conclusions}

1. Earthquake hazard zonation for urban areas, mostly referred as seismic microzonation, is the first and most important step towards a seismic risk analysis and mitigation strategy in densely populated regions

2. In the process of SMZ map development, the seismicity and seismic sources for a particular urban territory, the geological, ground motion, seismotectonic features and ground water conditions, including distribution of expected peak ground accelerations, shear wave velocity in typical grounds of territory from geotechnical data, depth to bedrock depth to water table and water level fluctuation were studied.

3. The calculation of the assigned weights for the thematic maps for GIS Integration and Normalised ratings layers was made.

4. The obtained values are then incorporated in a GIS platform for the integration of all the thematic maps to obtain the seismic microzonation map of Chennai city. The integration of five thematic layers is integrated by the UNION and overlay operation in GIS.

5. Using as initial data of the scenario synthesized records, for example, taking into account the characteristics of faults, takes into account the transformation of the original accelerograms stipulated by soil properties of the territory.

6. The complex approach based on the latest achievements of engineering seismology, can significantly increase the adequacy or reasonableness of assessments and reduce the inaccuracy in earthquake design and construction.

\section{References}

1. Abrahamson N.A., and Litehiser J.J. (1989) 'Attenuation of Vertical Peak Acceleration'. Bulletin of Seismological Society of America. Vol. 79. Pp. 549-580.

2. Ansal A., Erdik M., Studer J., Springman S., Laue J., Buchheister J., Giardini D., Faeh D., Koksal D. (2004) Seismic microzonation for earthquake risk mitigation in Turkey. In: Proceedings of the $13^{\text {th }}$ World Conference of Earthquake Engineering, Vancouver, BC, p. 1428.

3. Ansal A., Tönük G., Kurtuluş A. (2010) Microzonation for Earthquake Scenarios (Chapter 2) // Earthquake Engineering in Europe, ed. By M. Garevski, A. Ansal. Springer, 2010. Pp. 125-144.

4. Ayalew, L., Yamagishi, H., 2004. Slope movements in the Blue Nile basin, as seen from landscape evolution perspective. Geomorphology, 57(1-2): pp.95-116.

5. Ayalew, L., Yamagishi, H., Ugawa, N., 2004. Landslide susceptibility mapping using GIS-based weighted linear combination, the case in Tsugawa area of Agano River, Niigata Prefecture, Japan. Landslides, 1(1): pp. 73-81.

6. Barredo, J.I., Benavidesz, A., Herhl, J., van Westen, C.J., 2000. Comparing heuristic landslide hazard assessment techniques using GIS in the Tirajana basin, Gran Canaria Island, Spain. International Journal of Applied Earth Observation and Geoinformation, 2(1): pp. 9-23.

7. Beresnev I. A., Atkinson G. M. (1997). Modeling finite fault radiation from $\omega^{\mathrm{n}}$ spectrum. Bull. Seism. Soc. Am., 87, pp. 67-84. 
8. Beresnev I. A., Atkinson G. M. (1998). FINSIM - a FORTRAN program for simulating stochastic acceleration time histories from finite faults. Seismological Research letters. Vol. 69. No. 1.

9. BIS: 1893 (2001) 'Indian Standard, Criteria for Earthquake Resistant Design of Structures'. Bureau of Indian Standards. New Delhi.

10. Borcherdt R.D. (2001) 'Empirical Evidence for Acceleration-Dependent Amplification Factors'. Bulletin of the Seismological Society of America. Vol. 92. Pp. 761-782.

11. Borcherdt, R. D. and Glassmoyer, G. (1994) 'Influences of Local Geology on Strong and Weak Ground Motions Recorded in the San Francisco Bay Region and their Implications for Site-Specific Building-Code Provisions'. The Loma Prieta, California Earthquake of October 17, 1989-Strong Ground Motion. U. S. Geological Survey Professional Paper. Pp. 1551-A, A77-A108.

12. Boore D.M and Joyner (1982), "The empirical prediction of ground motion”, Bulletin of the Seismological Society of America, Vol. 72, pp. S43 - S60.

13. Census (2001) 'http.www.censusindia.com'

14. CGWB Report (1993) 'Groundwater Resources and Development Prospects in Madras District, Tamil Nadu'. Central Ground Water Board, Southern Region, Hyderabad.

15. El-Sayed A., Vaccari F., and Panz G.F. (2001), 'Deterministic seismic hazard in Egypt', Geophysical Journal International, Vol. 144, pp. 555-567

16. Ganapathy, G.P. (2005) 'Seismic Hazard Assessment for Tamil Nadu State and A Specific Study on Local Ground Motion Response for Part of Chennai City, Anna University, Ph.D. thesis (unpublished).

17. Gupta T.N. (2000) 'Guidelines - Improving Earthquake Resistance of Housing'. Published by Building Materials and Technology Promotion Council, New Delhi.

18. Imai T., and Yoshimura Y. (1970) 'Elastic Wave Velocity and Soil Properties in Soft Soil Tsuchi-to-Kiso’. Vol.18. No.1. Pp. 17-22.

19. Imtiyaz A.Parvez (2003) 'Seismic Microzonation: Methodology and Approach'. CSIR Centre for Mathematical Modelling and computer Simulation, Bangalore. Research Report, November 2003, p. 14.

20. Karl Terzaghi and Ralp B Peck (1967) 'Soil Mechanics in Engineering Practice'. Second Edition. John Wiley \& Sons. New Yark. P. 729

21. Nath, S.K (2004) 'Seismic Hazard Mapping in Sikkim Himalaya through GIS Integration of Site Effects and Strong Ground Motion Attributes. Natural Hazards. 31 (2). Pp. 319-342.

22. Ohba Y., and Goto, N. (1978) "Empirical shear wave velocity equations in terms of characteristics soil indexes", Earthquake Engineering Structural Dynamics, Vol. 6, pp. 167-187.

23. Saaty, T.L., 1980. The Analytical Hierarchy Process. McGraw Hill, New York, p. 350.

24. Siefko Slob, Robert Hack, Tom Scarpas, Bas van Bemmelen and Adriana Duque (2002) 'A Methodology for Seismic Microzonation Using GIS and Shake, A Case Study from Armenia, Colombia'. Engineering Geology for Developing Countries - Proceedings of $9^{\text {th }}$ Congress of the International Association for Engineering Geology and Environment Durban, South Africa, 16-20 September 2002. J.L. van Rooy and C.A. Jermy, editors. Pp. 2843-2852.

25. William K. Mohanty, M.Yangar Walling, Sankar Kumar Nath and Indrajit Pal, 
(2007) 'First Order Seismic Microzonation of Delhi, India Using Geographic Information System (GIS)'. Natural Hazards. Vol. 40. Pp. 245-260.

26.ZaalishviliV.B., Berezko A.E. (1999) View assessments seismic risk urban areas by using GIS//International Symposium "Engineering seismology and earthquake resistance". 19-21 May. --Tbilisi, 1999. P. 15

27.Zaalishvili V.B. (2000) Physical basis of seismic microzonation methods. M.: UIPE RAS, 2000. - 367 p.

28.Zaalishvili V.B.,Zaalishvili Z.V., OtinashviliShengelia, N. O. (2001) Method of rating territory for insurance purposes. Proceedings of the IV National Conference on earthquake-resistant construction and seismic zoning. - Sochi, 2001, p. 166.

29.ZaalishviliV.B., DjavrishviliI.A., Otinashvili M.G. (2001) Calculation of nonlinear vibration of soil thickness using numerical method of FEM "LIMIT-1" seismic microzonation//Proceedings of the IV National Conference on earthquake-resistant construction and seismic zoning. -Sochi, 2001, p. 44.

30.Zaalishvili V.B. (2006) Seismic microzonationbasis. Scientific Center RAS and RNO-A,-Vladikavkaz, 2006, 242 p.

31.Zaalishvili V. B., Melkov D. A., Burdzieva O. G. (2010) Determination of seismic impact on the basis of specific engineering-seismological situation of region // "Earthquake engineering. Buildings safety”, 2010 No.1. pp. 35-39 (in Russian).

DOI: 10.23671/NNC.2018.3.16554

\title{
ИСПОЛЬЗОВАНИЕ ГИС-ТЕХНОЛОГИЙ ПРИ СЕЙСМИЧЕСКОМ МИКРОРАЙОНИРОВАНИИ
}

\author{
() 2018 Г.П. Ганапатхи1, проф., В.Б. Заалишвили², д.ф.--м.н., проф., \\ Д.А. Мельков², К.т.н., В.Б. Свалова ${ }^{3}$, к.ф.-м.н., А.В. Николаев, д.ф.-м.н., проф. \\ 'Центр по смягчению и управлению стихийными бедствиями, Технологический \\ институт Веллора, Индия, 632014, Веллори,e-mail: seismogans@yahoo.com; \\ 2 Геофизический институт - фрилиал ФГБУН ФНЦ «Владикавказский научный \\ центр Российской академии наук», Россия, 362002, РСО-Алания, \\ г. Владикавказ, ул. Маркова, 93a, e-mail: cgi_ras@mail.ru;
}

${ }^{3}$ ФГБУН Институт геоэкологии им. Е.М. Сергеева, Россия, 101000, г. Москва, Уланский пер., д. 13, стр. 2, e-mail: inter@geoenv.ru

В работе представлен инструментарий в виде ГИС- технологий для составления карты сейсмического микрорайонирования. Рассмотрены методы и способы индийской и российской практики сейсмического микрорайонирования Реализована компиляция исходных данных в оперативную экспресс ГИС-методику. Построена карта сейсмического микрорайонирования первого уровня для города Ченнаи (Индия) с использованием ГИС-платформы на основе использования специфических информационных слоев в виде пикового ускорения грунта (PGA), скорости поперечной волны, геологического строения территории, уровня грунтовых вод и глубины кровли подстилающих коренных пород. Пиковое ускорение для сейсмических источников оценивалось на основе отношения затухания. При этом максимальное ускорение PGA для Ченнаи составило 0,176 g, а для Владикавказа - 0,2 g (для вероятности превышения 5\%). Анализ сейсмической опасности включал матрицы данных (дискретные наборы данных из разных тем были пре- 
образованы в сетки) для расчета окончательной матрицы сейсмической опасности путем интеграции и анализа веса исходных тематических слоев. Город Ченнай в процессе исследования был разделен на три обширные зоны: высокой, умеренной и низкой сейсмической опасности. Карта сейсмического микрорайонирования города Владикавказа была представлена в единицах шкалы MSK-64 и единицах ускорения.

В обоих рассмотренных подходах скорости поперечных волн были одной из основных инструментальных основ для соответствующих расчетов. Используя в качестве исходных данных сценариев синтезированные расчетные записи с учетом характеристик неисправностей, учитывается транссормация исходных акселерограмм, обусловленных свойствами почвы на территории.

Ключевые слова: сейсмическая опасность, микрорайонирование, геоинформационная система, рейтинг участка, акселерограмма 